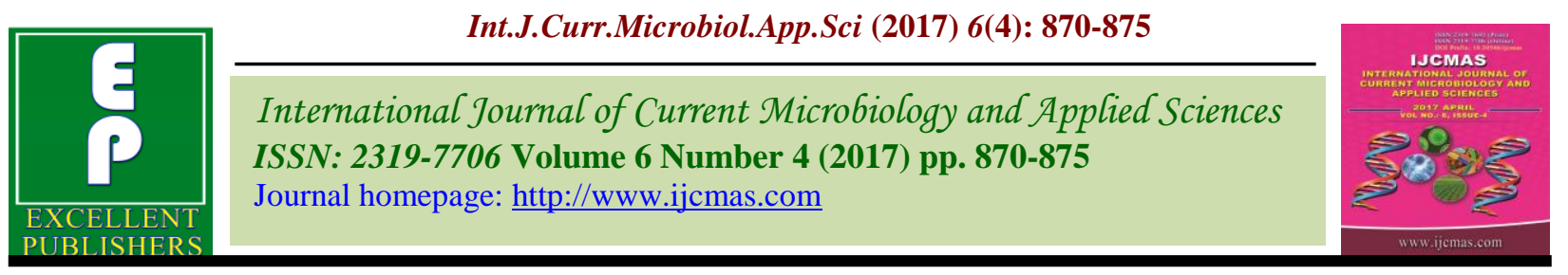

Original Research Article

https://doi.org/10.20546/ijcmas.2017.604.109

\title{
Symptomatology Studies of Soybean Mosaic Disease
}

\author{
H.V. Nandakishor*, Praful Kumar and S.S. Mane \\ Department of Plant Pathology, Dr. Panjabrao Deshmukh Krishi Vidyapeeth, \\ Akola, MS 444104, India \\ *Corresponding author
}

\begin{tabular}{|c|c|}
\hline & A B S T R A C T \\
\hline & \multirow{4}{*}{$\begin{array}{l}\text { Under field conditions, Soybean mosaic virus infected plants exhibited the } \\
\text { major symptoms viz., mosaic and mottling, crinkling, leaf puckering, } \\
\text { dwarfing and younger leaves showed clear mosaic symptoms etc. The SMV } \\
\text { Infected plants showed considerable reduction in plant height, pod length, } \\
\text { grains per pod and pods per plant that leads to considerable reduction in the } \\
\text { economic yield. The SMV was readily sap transmissible to cv. JS-335 } \\
\text { when the inoculum was prepared in } 0.1 \mathrm{M} \text { phosphate buffer (pH } 7.0 \text { ) and } \\
\text { produce typical symptoms such as mottling, crinkling of leaves, leaf } \\
\text { puckering and dwarfing. }\end{array}$} \\
\hline $\begin{array}{l}\text { Soybean mosaic } \\
\text { virus, JS-335, } \\
\text { Puckering, } \\
\text { Dwarfing }\end{array}$ & \\
\hline Article Info & \\
\hline $\begin{array}{l}\text { Accepted: } \\
\text { 06 March } 2017 \\
\text { Available Online: } \\
10 \text { April } 2017\end{array}$ & \\
\hline
\end{tabular}

\section{Introduction}

Soybean [Glycine max (L.) Merrill], 'Queen of Pulses', a native of Eastern Asia belongs to the family Leguminosae, subfamily Papilionoideae and tribe Phaseolae. Soybean is considered as a 'Golden bean', 'Miracle bean', 'Agriculture's Cinderella' and Wonder crop' of the $20^{\text {th }}$ Century' due to its qualities such as high protein $(40 \%)$, good amount of carbohydrates $(350 / 0)$, oil $(20 \%)$ and ash $(5 \%)$ content on oven dry basis. Soybean is known to be naturally infected by at least 50 viral diseases belonging to different groups (Sinclair, 1992). In India, so far 11 viruses have been reported to occur on soybean (Mali, 1995). Among the viral diseases, soybean mosaic virus (SMV) (Mali, 1995) seems to be much of prevalence. Clinton (1915) reported the occurrence of soybean mosaic virus for the first time in world. In
India the occurrence of soybean mosaic virus was reported from New Delhi by Nariani and Pingaley (1960). Later its occurrence was reported from Tamil Nadu (Usman et al., 1973), Uttar Pradesh (Singh et al., 1976) and Karnataka (Naik and Murthy, 1992). The primary leaves of infected plant curled down words, petioles and internodes shortened and plants were highly stunted. The virus was established on glasshouse grown soybean plants variety JS-335 by mechanical inoculation. Results of detailed studies made on this disease are reported in this paper.

\section{Materials and Methods}

For symptomatology studies soybean cv. JS335 was inoculated with SMV inoculum by following mechanical inoculation 
technique.The soybean plants showing typical mosaic, mottling, curling, less pubicent, puckering symptoms were collected from the fields and the samples were kept at $-80^{\circ} \mathrm{C}$ in plastic bags in deep freeze with proper labels. All frozen samples were then mechanically inoculated on propagation hosts. Frozen leaves were ground using chilled mortars and pestles in $0.1 \mathrm{M}$ Phosphate buffer ( $\mathrm{pH} 7.4$ ), containing $0.2 \%$ Sodium sulphite and $0.01 \mathrm{M} \quad \beta$ Mercaptoethanol. The fully grown leaves from six week old soybean cv JS-335 plants were rubbed with carborandum before being gently rubbed with the inoculums. Inoculated leaves were rinsed with tap water to remove the excess inoculum. The inoculated plants were maintained in glasshouse and observed regularly for symptom development. Observations were recorded on type and severity of symptoms and time taken for symptom development.The symptoms of virus infected symptomatic soybean plants under field conditions were observed. The differences between symptomatic and asymptomatic soybean plants based on their symptoms were studied under field conditions.

\section{Results and Discussion}

Symptoms of SMV observed were stunted plant growth, fewer pods that are sometimes dwarfed and flattened, without hairs and seeds. Trifoliate leaves exhibited mosaic with light and dark green areas that may become blistered or raised, particularly along the main veins. Leaves distorted, generally with the leaf margins curling downward. Primary leaves of some cultivars may show necrotic local lesions, which merge into veinal necrosis, followed by yellowing and leaf abscission (Fig. 1). These symptoms are similar to the findings of Byadgi et al., (2005), Baswaraj Raigond (2013), Balgude et al., (2012) and Amrita Banerjee et al., (2014).

All the plants of soybean cv. JS-335, inoculated by following sap inoculation technique, showed light and dark green mosaic on upper leaves after 10-14 days of inoculation. In extreme cases leaves were dark green with vein clearing of the leaves. Leaf margins were curved downward at the sides.

Table.1 Comparison of symptomatic and asymptomatic plants based on pod length, test weight, plant height, grains per pod and pods per plant

\begin{tabular}{|l|l|l|l|l|l|l|}
\hline $\begin{array}{l}\text { Sr. } \\
\text { No. }\end{array}$ & Samples & $\begin{array}{l}\text { Pod length } \\
(\mathbf{c m})\end{array}$ & $\begin{array}{l}\text { 100 grains } \\
\text { weight }(\mathbf{g m s})\end{array}$ & $\begin{array}{l}\text { Plant } \\
\text { height(cm) }\end{array}$ & $\begin{array}{l}\text { Grains } \\
\text { per pod }\end{array}$ & $\begin{array}{l}\text { Pods per } \\
\text { plant }\end{array}$ \\
\hline \multirow{2}{*}{1} & Asymptomatic & $5.6 \mathrm{~cm}$ & 15.20 & $45 \mathrm{~cm}$ & 6 & 25 \\
\cline { 2 - 7 } & Symptomatic & $3.2 \mathrm{~cm}$ & 12.90 & $30 \mathrm{~cm}$ & 3 & 22 \\
\hline \multirow{2}{*}{2} & Asymptomatic & $5.8 \mathrm{~cm}$ & 15.90 & $40 \mathrm{~cm}$ & 8 & 26 \\
\cline { 2 - 7 } & Symptomatic & $3.5 \mathrm{~cm}$ & 13.15 & $25 \mathrm{~cm}$ & 5 & 19 \\
\hline \multirow{2}{*}{3} & Asymptomatic & $6 \mathrm{~cm}$ & 14.20 & $45 \mathrm{~cm}$ & 6 & 22 \\
\cline { 2 - 7 } & Symptomatic & $4 \mathrm{~cm}$ & 11.21 & $25 \mathrm{~cm}$ & 3 & 15 \\
\hline 4 & Asymptomatic & $6.5 \mathrm{~cm}$ & 16.10 & $35 \mathrm{~cm}$ & 5 & 18 \\
\hline \multirow{2}{*}{5} & Symptomatic & $4 \mathrm{~cm}$ & 12.88 & $15 \mathrm{~cm}$ & 3 & 14 \\
\hline & Asymptomatic & $6.2 \mathrm{~cm}$ & 15.80 & $50 \mathrm{~cm}$ & 6 & 20 \\
\hline
\end{tabular}


Figure.1 Soybean plants showing different symptoms after inoculation with SMV
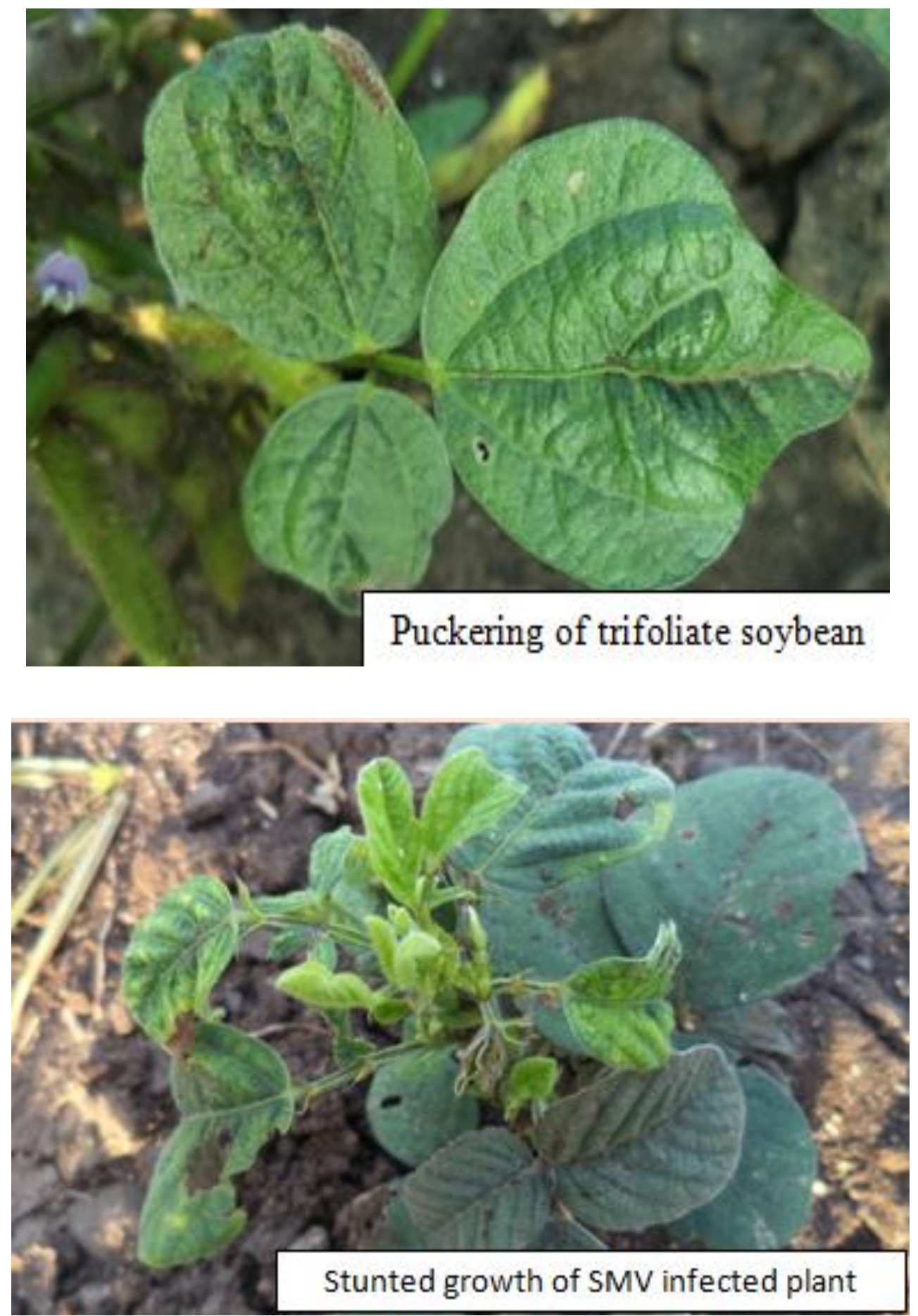

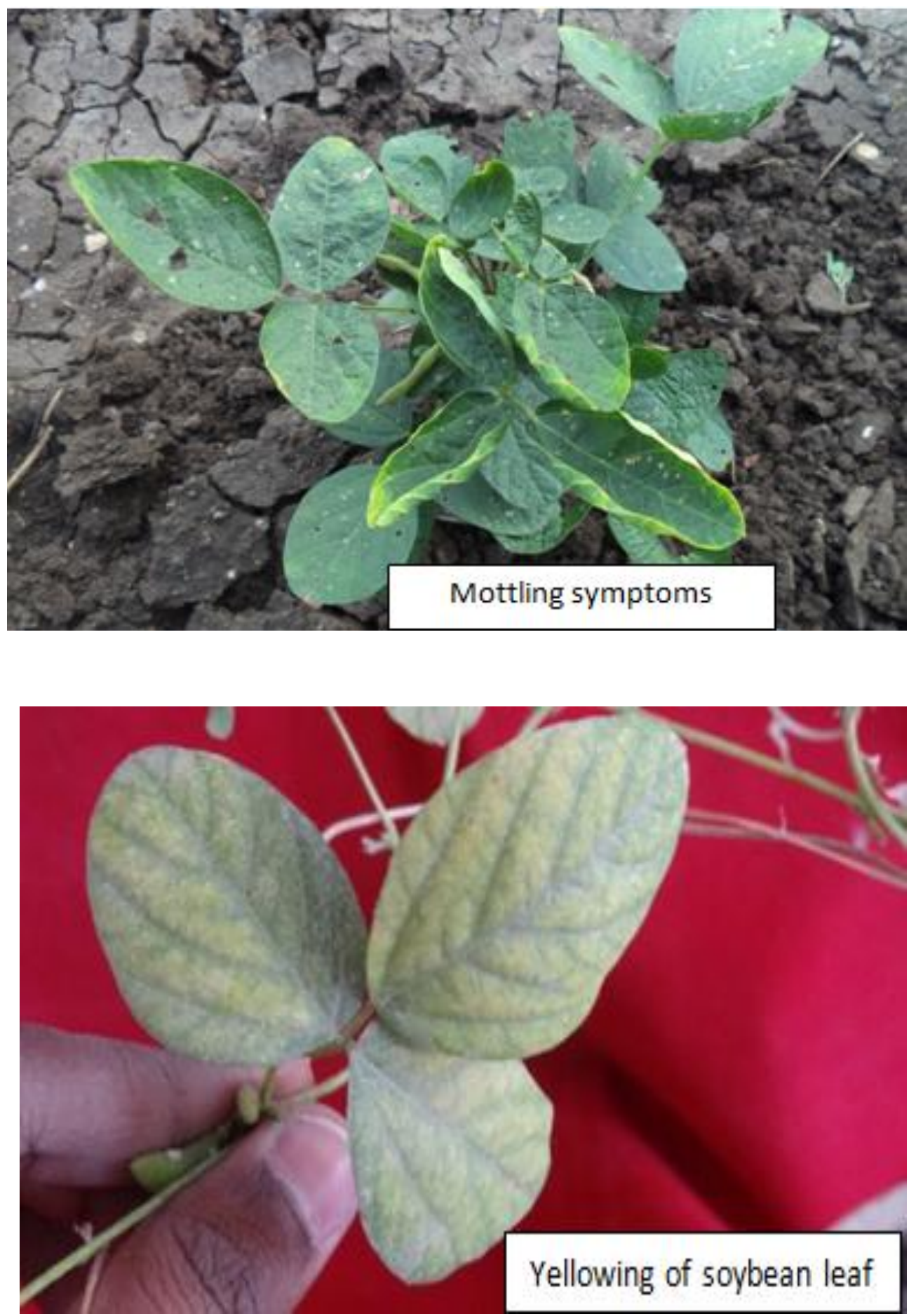

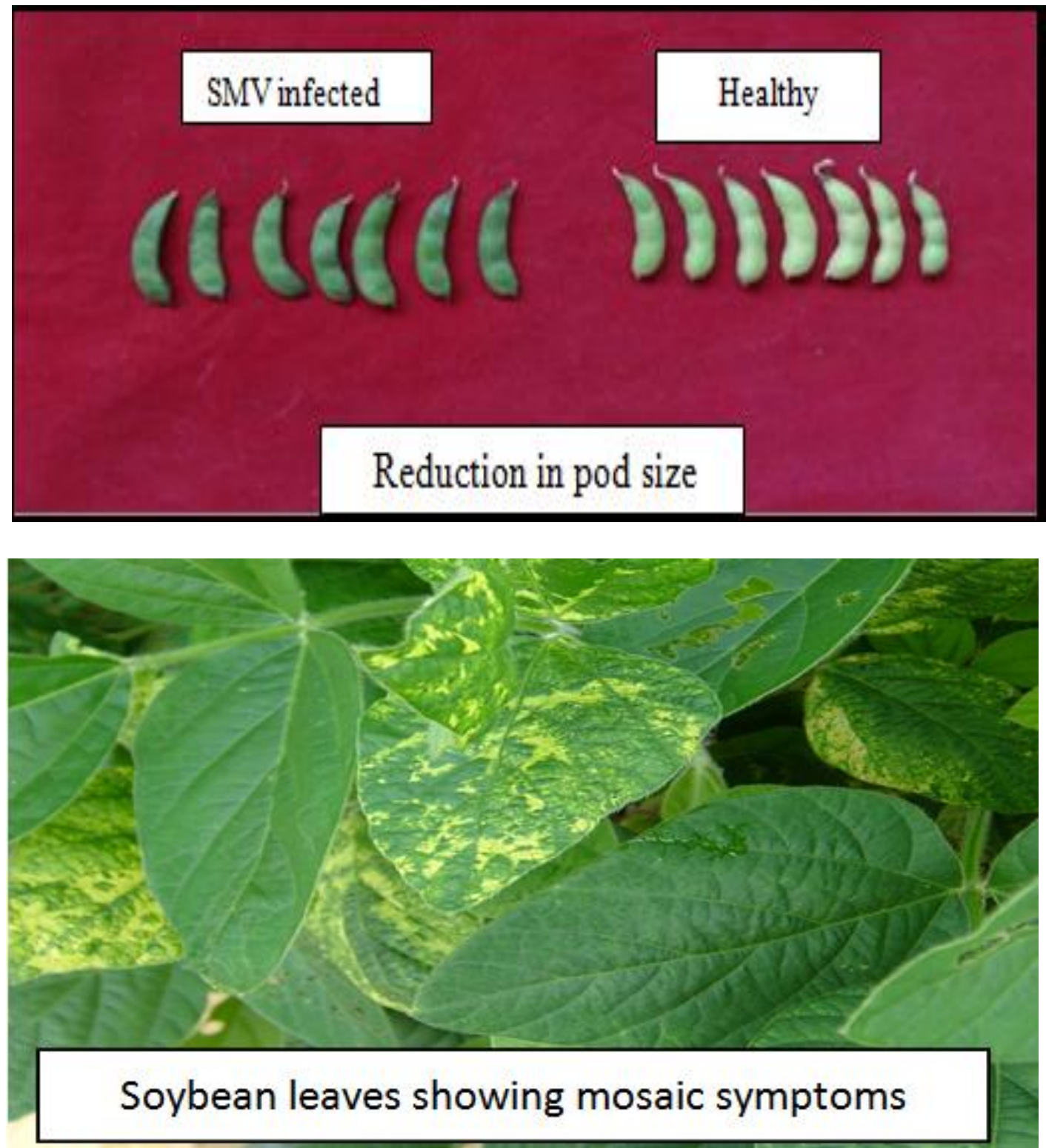

Affected leaves were coarse, leathery to touch and somewhat brittle at maturity. Symptoms began to vanish on ageing and older leaves remained symptomless. The infected plants were stunted growth with reduction in leaf size and also reduction in pod size.

Data in table 1 showed that Asymptomatic plants produced healthy pods with maximum yield $(90 \%)$ but in symptomatic plants pod formation was greatly reduced with stunted growth. Symptomatic plants were dark green with mosaic, leaf distortion, light and dark green mosaic, dark green with vein clearing and in severe condition yield losses around 90 $\%$. Where asymptomatic plants produced a large minority of three-seeded pods (34.2\%), a majority $(54.5 \%)$ of two-seeded pods and only $9.2 \%$ of single-seeded pods, in contrast, a symptomatic plant produced either no pods at all, or a highly reduced i.e. $7.5 \%$ of threeseeded pods, $15.2 \%$ of two-seeded and $8.3 \%$ of single-seeded pods. Asymptomatic plants produced very few sterile pods per plant 
(almost 2.2\%), but symptomatic plants had $77.3 \%$ sterile or empty pods per plant, the main cause of severe yield losses.

\section{References}

Amrita, B., Chandra, S. and Sharma, S.K. 2014. First molecular evidence of Soybean mosaic virus (SMV) infection in soybean from India Plant Pathology, ICAR Research Complex for NEH Region, Umiam, Meghalya 793103, India.

Balgude, Y.S., Sawant, D.M. and Gaikwad, A.P. 2012. Transmission studies of Soybean mosaic virus J. Pl. Dis. Sci., 7(1): $52-54$.

Baswaraj, R., Sharma, M., Chauhan, Y., Jeevalatha, A., Singh, B.P. and Sharma, S. 2013. Optimization of duplex RTPCR for simultaneous detection of Potato virus Y and S. Potato J., 40(1): 22-28.

Clinton, G.P. 1916. Reports of the botanist for 1915: Soybeans. Annual Report, Connecticut Agri. Experiment Station, p. 446.

Mali, V.R. 1995. Profile of viruses naturally infecting Soybean in Marathawada. Proceedings of the 10th Annual Convention Indian Society for Virology and National Symposium, Viral Diseases of Socio- Economic Importance Relevant to India, Jan. 1618, SCTIMST, Dept. Microbiol, Trivandrum, India, pp: 34.

Naik, R.G. and Keshavmurthy, R.V. 1992. Characterization of a virus causing mosaic on Soybean [Glycene $\max (\mathrm{L}$. Merr.] from Karnataka. Legume Res., 15(1): 19-23.

Nariani, T.K. and Pingale, K.V. 1960. A mosaic disease of Soybean [Glycene $\max (\mathrm{L}$.$) Merr.). Indian Phytopathol.,$ 13: $130-136$.

Patil, R.G. and Byadgi, A.S. 2005. Transmission Studies of Soybean mosaic virus. Karnataka J. Agric. Sci., 18(1): 52-54.

Sinclair, J.B. 1977. Infectious soybean disease of world importance. Proceedings Academy of Natural Sciences, Philadelphia, 23: 49-57.

Singh, B.R., Singh, O.K. and Saxena, H.K. 1976. A Mosaic disease of Soybean at Kanpur, India. Sci. Culture, 42: 53-54.

Usman, K.M., Ranganathan, K., Kandaswamy, T.K., Damodaran, A.P.S. and Ayyvoo, R. 1973. Studies on a mosaic disease of soybean. Madras Agril J., 60: 472-474.

\section{How to cite this article:}

Nandakishor, H.V., Praful Kumar and Mane, S.S. 2017. Symptomatology Studies of Soybean Mosaic Disease. Int.J.Curr.Microbiol.App.Sci. 6(4): 870-875.

doi: https://doi.org/10.20546/ijcmas.2017.604.109 